\title{
Managerial Behavior, Environmental Dynamics and Organizational Performance
}

\section{Mohammad Ikram Ramzi, Rikinorhakis Ridzwan, Wan Mohd Firdaus Wan Mohamad}

To Link this Article: http://dx.doi.org/10.6007/IJARBSS/v11-i11/11504

DOI:10.6007/IJARBSS/v11-i11/11504

Received: 06 September 2021, Revised: 10 October 2021, Accepted: 30 October 2021

Published Online: 14 November 2021

In-Text Citation: (Ramzi et al., 2021)

To Cite this Article: Ramzi, M. I., Ridzwan, R., \& Mohamad, W. M. F. W. (2021). Managerial Behavior, Environmental Dynamics and Organizational Performance. International Journal of Academic Research in Business and Social Sciences, 11(11), 1900-1912.

Copyright: (c) 2021 The Author(s)

Published by Human Resource Management Academic Research Society (www.hrmars.com)

This article is published under the Creative Commons Attribution (CC BY 4.0) license. Anyone may reproduce, distribute, translate and create derivative works of this article (for both commercial and non0-commercial purposes), subject to full attribution to the original publication and authors. The full terms of this license may be seen at: http://creativecommons.org/licences/by/4.0/legalcode

Vol. 11, No. 11, 2021, Pg. $1900-1912$

Full Terms \& Conditions of access and use can be found at http://hrmars.com/index.php/pages/detail/publication-ethics 


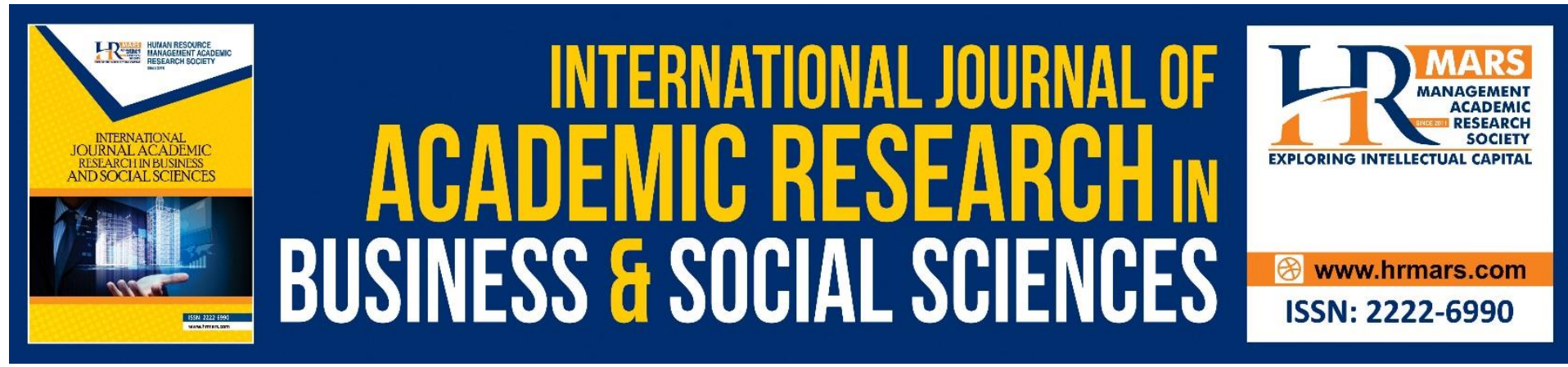

\title{
Managerial Behavior, Environmental Dynamics and Organizational Performance
}

\author{
Mohammad Ikram Ramzi, Rikinorhakis Ridzwan, Wan Mohd \\ Firdaus Wan Mohamad \\ Faculty of Business and Management, Universiti Teknologi Mara, Kelantan, Malaysia
}

\begin{abstract}
The performance of organizational reflects the result of the implementation of various strategies adopted by the organization. Different organizations use varying measures of performance. A recent study suggests that managerial practices are strongly connected with firm or organizational performance. A previous study discovered significant disparities in management practices among organizational and nations, and that these practices were closely linked to organizational innovation and other performance indicators including profitability and survival rates. From that, this study aims to propose a model based on the combination of managerial leadership, managerial competence, and managerial ties toward organizational performance. Also, this study highlights the role of environmental dynamics as a moderating variable. Thus, disparities in management practices were discovered to be bigger within nations than across countries, showing that some organizational and industrial elements are at least as important as the overall business environment in shaping management performance. This is due to the organization's significant contribution to a country's economic development.
\end{abstract}

Keywords: Environmental Dynamics, Managerial Behavior, Managerial Competence, Managerial Leadership, Managerial Ties, Organizational Performance.

\section{Introduction}

Accordingly, the performance of the organization refers to a company's market success, which can take several forms. It depends on their management capability to lead to the creation of employment and wealth by business start-up, survival and sustainability. In business studies, organizational performance is a hot topic. It is, nevertheless, a multifaceted and complex phenomenon. The ability of a company to provide acceptable outcomes and actions is referred to as performance (Chittithaworn et al., 2011; Kamasak, 2017). The achievement of goals and objectives in any sector of human existence is vital to a company's success. Although it is not often clearly stated, success is a vital phrase in the field of management where it can increase organizational performance. Success and failure can be viewed as indicators of effective or ineffective management. The term "success" is frequently used in business studies to refer to a company's financial performance. However, there is no commonly agreed upon definition of success, and the term has been defined in a variety of ways in the business world. At least two key elements of success exist: 1 ) financial vs. other 
success; and 2) short-term vs. long-term success. As a result, success can take various forms, such as survival, profit, return on investment, sales growth, employee count, happiness, reputation, and so on. In other words, success might be seen differently by different people. Despite these disparities, people appear to have a common understanding of the phenomenon, i.e., what type of organizational is successful (Chittithaworn, et al., 2011; Swab \& Johnson, 2019).

Research on organizational performance is a long-studied topic in which some academics say that there are two techniques in examining an organization's performance. One is purely economic in nature, emphasizing the significance of external market forces in determining organizational performance (Atallah, Bousmah, \& De Fuentes, 2021). The alternative line of inquiry, which is based on the behavioral and sociological perspective, considers organizational variables and their fit with the environment to be the most important determinants of success. According to McGahan and Porter (1997), many academics from various backgrounds have focused on explaining organizational performance and identifying the causes of performance differences between organizational. For example, Chang and Singh (2000) have argued that the structure of the industry is a key determinant in deciding the performance of the organizational as well as the structural characteristics, the effects of the industry and the competitive position of business units within a particular industry. The incapacity of traditional industries (the organization to provide a rigorous explanation for intra-industry performance variability) has prompted scholars to concentrate on organizational strategy (Atallah, Bousmah, \& De Fuentes, 2021; Chang \& Singh, 2000).

When it comes to behavior management, some researchers have pointed out that it is related to "what managers do" or "something made by a manager" that can affect the performance of the company or organizational (Kopelman, 2019). Therefore, managerial behavior is based on the theory of Mintzberg (1973), which Mintzberg has explained that the work of managers consists of three basic elements. First, they begin by interacting with others. Second, they are information processors. Finally, they make decisions. Another fundamental component of management activity has been recognized in a broader conception. In addition to these "managerial" responsibilities, all managers engage in operational labor to varying degrees. In order to ensure the success of the organizational, Mehta, Dubinsky and Anderson (2003) stated that managerial behavior will be more effective if environmental factors are considered such as new technologies, globalization, changing social and political climates, new competitive threats and so on (Ahlstrom, et al., 2020; Javalagi, Griffith \& White, 2003).

The degree of achievement of the mission at work that contributes to an employee's job performance is referred to as performance (Ciobanu, Androniceanu, \& Lazaroiu, 2019). Performance is viewed differently by different academics. The term "performance" was commonly used by researchers to describe a wide range of measurements of transactional efficiency, as well as input and output efficiency (Stannack, 1996). Performance is a neverending process that is a source of debate among organizational researchers. The term "organizational performance" refers not only to the definition of a problem, but also to the resolution of that problem (Pinto, 2019). Due to the ever-changing and evolving environment, organizational must adapt or risk losing their competitive edge. As a result, firms test new business models, products, services, and procedures, among other things (Xu et al., 2007). Furthermore, innovation is one of the environmental factors which have been seen as critical for supporting organizational performance and managerial behaviors (Garcia, 1998; Hansen, 2006). This gap has motivated the researcher to investigate the contribution of environmental 
dynamic to organizational performance in relation to managerial behaviors (e.g.: managerial leadership, competence, and ties) possessed by different level of managers. Accordingly, the objectives of the study are as follows:

- To identify whether the factors of managerial behaviors (managerial leadership, competence, and ties) influence the organizational performance

- To examine the moderating effect of environmental dynamics in the relationship between managerial behaviors (managerial leadership, competence, and ties) and organizational performance.

\section{Literature Review}

\section{Organizational Performance}

Accordingly, organizational performance refers to ability of an organizational to achieve such objectives as high profit, quality product, large market share, good financial results, and survival at pre-determined time using relevant strategy for action (Danso, Kong, Akomeah, \& Afriyie, 2018; Koontz \& Donnell, 1993). Organizational performance can also be used to view how an organizational is doing in terms of level of profit, market share and product quality in relation to other enterprises in the same industry. Consequently, it is a reflection of productivity of members of an enterprise measured in terms of revenue, profit, growth, development and expansion of the organization (Obiwuru, et al., 2011). Sandberg, Vinberg and Pan (2002) had defined the performance of organizational as "their capability to lead to the creation of employment and wealth by business start-up, survival and sustainability" (Sandberg et al., 2002). On the other hand, researchers studying strategic management have recommended multiple measures of organizational performance. Recently, Benrqya and Jabbouri (2021) used three measures of organizational performance namely, return of assets indicating profitability, growth in sales indicating how well customers accept the organizational products or services, and price cost margin.

Paul and Anantharaman (2003) measured organizational performance along two dimensions, which are operational and financial. Measures of operational performance included employee retention, productivity, product quality, delivery speed, and operating costs. Sales growth, net profit, and return on investment were used to evaluate financial performance. While, according to Nguyen et al (2021), organizational performance is measured in both financial and nonfinancial terms. Return on assets (ROA), market share, Return on Investment (ROI), Operating Profit of Organizational (EBIDTA), and growth rates in domestic and export sales are among the financial indicators. Previous researchers have employed similar methods (e.g.: Hitt, \& Irelend, 1985). Management's perceptions of productivity, profitability, market share, and customer satisfaction relative to competitors are also nonfinancial performance measures. Chan and Qi (2003) stated that if precise objective metrics are unavailable, non-financial performance measures could be used. Several researchers have employed subjective performance metrics (e.g.: Li, 2000, Akimova, 2000). The question of how to assess business success has long been disputed, but traditional economic theory has placed a strong focus on market power and industry structure as determinants of organizational performance (Chandler, 1994; Knight, 1997; Wiklund, 1999). Switzer and Bourdon (2011), on the other hand, have emphasized the importance of managerial ability (Abubakar et al., 2019), with Mintzberg (1973) explaining that managers' work consists of three basic elements: (1) they interact with others (managerial ties), (2) they process information (managerial competence), and (3) they make decisions (managerial 
leadership).

\section{Managerial Leadership}

The concept and definition of managerial leadership and style may differ from one person or situation to the next. The word "leadership" has been used in various aspects of human endeavor, such as politics, business, academics, social works etc. Previous views about leadership show it as a personal ability. Messick and Kramer (2004) argued that the degree to which an individual exhibits leadership traits depends not only on his characteristics and personal abilities, but also on the characteristics of the situation and environment in which he finds himself. Since human beings could become members of an organization in other to achieve certain personal objectives, the extent to which they are active members depends on how they are convinced that their membership will enable them to achieve their predetermined objectives. Therefore, an individual will support an organization if he believes that through it his personal objectives and goals could be met; if not, the person's interest will decline. Leadership style in an organization is one of the factors that play a significant role in increasing or decreasing the interest and commitment of individuals in the organization (Mahmoud, 2020). Thus, a previous study by Glantz (2002) emphasizes the need for a manager to find his leadership style.

Understanding the effects of leadership on performance is especially significant because some studies believe that leadership is one of the most critical factors in enhancing a company's performance. Effective leadership is regarded as a valuable source of managerial development and a long-term competitive advantage for improving organizational performance (Avolio, 1999; Lado, Boyd \& Wright, 1992; Rowe, 2001). For instance, transactional leadership helps organizations achieve their current objectives more efficiently by linking job performance to valued rewards and by ensuring that employees have the resources needed to get the job done (Zhu, Chew \& Spengler, 2005). Visionary leaders create a strategic vision of some future state, communicate that vision through framing and use of metaphor, model the vision by acting consistently, and build commitment towards the vision (Avolio, 1999; Danso, et al., 2018; McShane \& Von Glinow, 2000). Visionary leadership, according to certain experts such as Zhu, Chew, and Spengler (2005), will result in high levels of cohesion, commitment, trust, motivation, and hence performance in new organizational environments.

\section{Managerial Competence}

Cheng, Dainty, and Moore (2003) argue that research on managerial competence is narrowly focused and confusing in its terminology. The concept of competence is viewable from several perspectives. For example, competence is quantifiable as predictive competence (i.e., testing the characteristics and aptitudes that are likely to differentiate superior performers), organizational core competencies (i.e., aggregates of capabilities, where synergy is created that has sustainable value and broad applicability for an organization), proven competence (i.e., a real and demonstrated ability to successfully carry out some activity which is totally identified), as well as adaptive competence (i.e., the ability to read a new situation and adapt/apply appropriate competences). Hogg (1993) argues that predicting a person's competences based on performance is impossible. Other researchers believe that competencies are the factors that affect the success of performance in a job or situation. Such competencies embed in organizational history and culture, and produce complex social relationships, as well as generate tacit organizational knowledge (Barney, 1992; Reed \& 
DeFillippi, 1990; Tian, \& Zhai, 2019; Wright \& McMahan, 1992).

Competency profiling is a method of determining one's primary accountability for one's competencies and critical outputs. These specify what the role holder must be able to do and the behavior expected of him or her in order to effectively fulfil the function (Armstrong, 2000; Rodriguez, \& Walters, 2017). According to Armstrong (2000), executives consistently emphasize certain characteristics of competence that are: (a) related to realistic workplace practices, (b) expressed as an outcome rather than a procedure or process, (c) observable and assessable, (d) not contain evaluative statements, but rather be tied to performance criteria against which they will be evaluated, (e) sensible and specific and not subject to various interpretations, and ( $f$ ) observable and assessable. Thus, the establishment of the competency of individuals is crucial for further development of an organization (Cheng et al., 2003). All organizations distinguish between behavior-based competencies that relate to "how the executive acts" and attribute-based competencies that refer to "who the executive is" (Jurie, 2000). Competency is the underlying characteristic of an individual that relates causally to effective or superior performance (Boyatzis, 1982). Armstrong (2000) also notes that in the process of establishing what executives are able to do, and the behavior required of them to perform the role effectively, their competence profiles must be created.

\section{Managerial Ties}

According to Puffer, McCarthy, Jaeger, and Dunlap (2013), managerial ties (or networks) are a significant tool for favor management. Managerial relationships (e.g., ties with managers at other enterprises and links with government officials) have long been considered to be an area dominating managers' attention in emerging economies in the absence of formal market supporting structures (Peng \& Heath, 1996; Puffer et al., 2013). Both types of ties have been shown to have an impact on organizational performance in emerging economies such as China (Li, Poppo, \& Zhou, 2008; Peng \& Luo, 2000), Ghana (Acquaah, 2007), Hungary (Danis, Chiaburu, \& Lyles, 2010), Russia (Puffer and McCarthy, 2007), and South Korea (Puffer \& McCarthy, 2007). Scholars argue that the more market-supporting institutions are developed, the less need managers may feel about devoting time and resources to cultivate managerial ties (Danis et al., 2010; Peng, 2003; Zhou, Poppo, \& Yang, 2008). Previous studies have used single country data, the theoretical claim for the importance of managerial ties has yet to be tested with cross-country (as opposed to single country) data (Zhou, Poppo, \& Yang, 2008).

A relational tie is a linkage between two actors (Wasserman \& Faust, 1994). Managerial ties, which are one specific type of relational ties, were defined as "executives' boundary-spanning activities and their associated interactions with external entities" (Geletkanycz \& Hambrick, 1997; Wang, Guo, \& Liu, 2017). Peng and Luo (2000) demonstrated a link between managerial ties and organizational performance. Studies by others have also shown that certain characteristics of managerial network ties are related to the performance of entrepreneurial organizational (Hoang \& Antoncic, 2003; Johannisson, 2000). For example, some studies have found relationships between network strength (strong ties vs. weak ties) and organizational performance (Bruderl \& Preisendorfer, 1998; McEvily \& Zaheer, 1999). Among the many definitions, Batjargal (2003) defined strong ties as ties with friends ("those with whom you have non-reciprocal and altruistic relationships,") and weak ties as ties with acquaintances ("those with whom you have reciprocal relationships,"). At the same time, Ahuja (2000a) also found that managerial network density is more beneficial for organizational innovative performance. In contrast, research has also found that organizational embedded in a sparse network structure exhibit greater revenue growth 
(Baum, Calabrese \& Silverman, 2000) and enjoy greater market share (Pratono, 2018; Zaheer \& Bell, 2005).

\section{Environmental Dynamics}

Individuals and businesses operating in dynamic contexts face unpredictable and rapid change, which adds to their uncertainty (Conz, \& Magnani, 2020; Duncan, 1972; Dess \& Beard, 1984). The discrepancy between expected and actual outcomes is known as uncertainty, and it arises from the restricted availability of information for decision-making (Simon, 1955). Decision makers working in dynamic situations face larger information processing loads due to high levels of uncertainty (Tushman, 1979). As a result, these people are more likely to suffer from excessive levels of stress and worry (Waldman et al., 2001). This effect can be minimized to some extent by dividing decision-making tasks among top management teams (Hambrick \& Mason, 1984; Pearce \& Conger, 2003; Pearce, 2004).

Some of the most intriguing research in dynamics has focused on the environment's moderating effect on the relationship between top management team composition and organizational performance. According to Hambrick and Mason (1984), diverse top management teams function best in dynamic contexts, while homogenous teams perform better in more stable environments. According to these writers, diverse teams are more capable of making sense of ambiguous situations than less diverse teams, which are more likely to function with a narrower perspective. Priem (1990) agrees with Hambrick and Mason (1984), but adds that the level of consensus within senior management teams is likely to be related to performance, with low consensus teams doing best in dynamic contexts and high consensus teams performing best in stable environments. In support of these opposing viewpoints, Homburg et al. (1999) discovered that senior management team consensus has a smaller impact on performance in dynamic rather than stable situations (Bang \& Midelfart, 2017).

\section{Theoretical Framework}

Accordingly, it has been confirmed that managerial behavior affects organizational performance which leads to success in business (Turner \& Endres, 2017). The managerial behaviors consists of three elements which are managerial leadership (Mahmoud, 2020), managerial competence (Cheng et al., 2003) and managerial ties (Puffer \& McCarthy, 2007). All these elements will use for this study to investigate whether the factors of managerial behavior will increase the organizational performance. At the same time, Mehta et al (2003) had stated that the relationship between managerial behavior and firm performance will be more increase and be more effective if environmental factors are considered such as new technologies, globalization, changing social and political climates, new competitive threats and so on.

Contingency theory has been widely used in researches on measuring the performance and effectiveness of an organization and it claims that there is no optimum method to systematize a firm and the organization structure of the company (Fiedler, 1964). In other words, contingency theory argues that the most appropriate structure for an organization is the one that best fits a given operating contingency, such as technology (Woodward, 1965) or environment (Burns \& Stalker, 1961). Therefore, based on the literature review and support of Contingency Theory by House (1977), researcher will use the factor of environmental dynamic as a moderating effect in enhancing the relationship between managerial behavior and organizational performance. Then, a theoretical framework was 
constructed for the present study as depicted in figure 1 below:

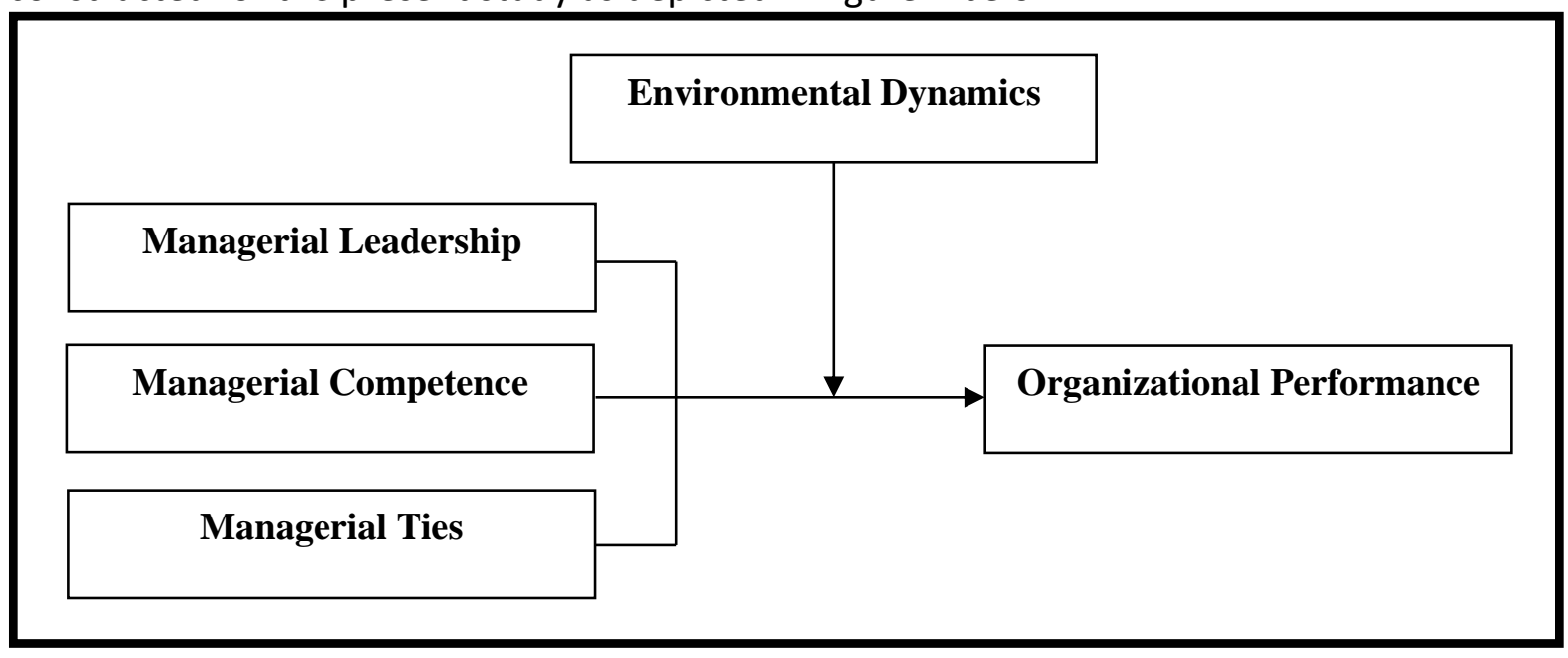

Figure 1: Theoretical Framework

\section{Findings, Discussion and Conclusions}

From the previous arguments, it is show that the important role of managerial behaviors toward organizational performance. Managerial leadership in particular of management team characteristics have also been shown to be predictors of organizational behavior and performance. The argument is that the management background; in particular values and experiences are associated to organizational strategies and performance. Simultaneously, the relationship between organizational performance and leadership characteristics has been widely studied. Also, managerial competencies have long been considered a significant factor in an organizational performance because they enable the organizational to develop, combine, and transform resources (physical, financial and managerial) into value offerings. Thus, competences are more than just an indicator of overall export capabilities; they are also a predictor of an organizational ability to launch and sustain regular exporting. Furthermore, with increased competition, rapidly changing consumer demands and desires, and shorter product life cycles, enterprises must improve their ability to discover, create, and deliver higher customer value in export markets than their competitors. In terms of managerial ties' impact on organizational performance, networks stabilize economic activities by having members engage in reciprocal, preferential, and mutually supportive action. Networks provide flexibility of resource allocation in an environment where needed factor mobility is severely constrained. Puffer et al (2013) also had discussed in their studied that managerial ties have been documented to impact organizational performance in emerging economies in certain countries like China, Ghana, Hungary, Russia, and South Korea. At the same time, the influence of environment on an organizational strategic behavior and structural arrangements is well documented in the strategic management literature. The fit between environment, strategy and structure has been often shown to be a predictor of performance. Further, to strive for better performance, organizational also need to develop capabilities in market-based strategic initiatives, such as developing new product lines and introducing new technologies. Therefore, the intervention of environmental dynamic between managerial behaviors (e.g.: managerial leadership, managerial competence, managerial ties) and organizational performance will lead to better organizational success. 


\section{References}

Abubakar, A. M., Elrehail, H., Alatailat, M. A., \& Elçi, A. (2019). Knowledge management, decision-making style and organizational performance. Journal of Innovation \& Knowledge, 4(2), 104-114.

Acquaah, M. (2007). Managerial social capital, strategic orientation, and organizational performance in an emerging economy. Strategic Management Journal, 28, 12351255.

Ahlstrom, D., Arregle, J. L., Hitt, M. A., Qian, G., Ma, X., \& Faems, D. (2020). Managing technological, sociopolitical, and institutional change in the new normal. Journal of Management Studies, 57(3), 411-437.

Ahuja, G., \& Lampert, C. M. (2001). Entrepreneurship in the large corporation: A longitudinal study of how established firms create breakthrough inventions. Strategic Management Journal, 22(6-7), 521-543.

Armstrong, M. (2000). Performance management: Key strategies and practical guidelines. London: Kogan Page.

Atallah, G., Bousmah, I., \& De Fuentes, C. (2021). Previous intrapreneurship experience as a determinant of entrepreneurial activity and performance. Economics of Innovation and New Technology, 1-18.

Avolio, B. J. (1999). Full leadership development: Building the vital forces in organizations. Thousand Oaks: CA Sage.

Bang, H., \& Midelfart, T. N. (2017). What characterizes effective management teams? A research-based approach. Consulting Psychology Journal: Practice and Research, 69(4), 334.

Barney, J. B. (1992). Integrating organizational behavior and strategy formulation research: A resource-based analysis. In Shrivastava, P., Huff, A. and Dutton, J, (Eds.), Advances in Strategic Management, 39-61. Greenwich, CT: JAI Press.

Batjargal, B. (2003). Social capital and entrepreneurial performance in Russia: A longitudinal study. Organization Studies, 24(4), 535-556.

Baum, J. A. C, Calabrese, T., \& Silverman, B. S. (2000). Don't go it alone: Alliance network composition and start-ups' performance in Canadian biotechnology. Strategic Management Journal, 21(3), 267-294.

Benrqya, Y., \& Jabbouri, I. (2021). Performance evaluation of European grocery retailers: A financial statement analysis. International Journal of Logistics Economics and Globalisation, 9(1), 24-39.

Boyatzis, R. E. (1982). The competent manager: A model for effective performance. New York: Wiley.

Bruderl, J., \& Preisendorfer, P. (1998). Network support and the success of newly founded business. Small Business Economics, 10(3), 213-225.

Burns, T., \& Stalker ,G.M.(1961). The management of innovation. London: Tavistock.

Chan, F. T. S., \& Qi, H. J. (2003), "An innovative performance measurement method for supply chain management", Supply Chain Management, (83/4), 209-223.

Chandler, G., \& Hanks, S. (1994), "Market attractiveness, resource-based capabilities, venture strategies and venture performance" Journal of Business Venturing, (94), 331-339.

Chang, S., \& H. Singh. (2000). Corporate and industry effects on business unit competitive position. Strategic Management Journal, 21(7), 739-752.

Cheng, M., Dainty, A., \& Moore, D. (2003). The differing faces of managerial competency in Britain and America. Journal of Management Development, 22(6), 527-537. 
Chittithaworn, C., Md. Aminul, I., Keawchana, T., \& Dayang Hasliza, M. Y. (2011). Factors affecting business success of small \& medium enterprises (SMEs) in Thailand. Asian Social Science, 7 (5), 180-190.

Ciobanu, A., Androniceanu, A., \& Lazaroiu, G. (2019). An integrated psycho-sociological perspective on public employees' motivation and performance. Frontiers in Psychology, 10, 1-7.

Conz, E., \& Magnani, G. (2020). A dynamic perspective on the resilience of firms: A systematic literature review and a framework for future research. European Management Journal, 38(3), 400-412

Danis, W., Chiaburu, D., \& Lyles, M. (2010). The impact of managerial networking intensity and market-based strategies on firm growth during institutional upheaval: A study of small and medium-sized enterprises in a transition economy. Journal of International Business Studies, 41, 287-307.

Danso, P. O., Kong, Y., Akomeah, M. O., \& Afriyie, S. O. (2018). An empirical analysis of the relationship between leadership and organizational performance. American Journal of Multidisciplinary Research, 7(1): 956-963.

Dess, G. G., \& Beard, D. W., (1984). Dimensions of organizational task environments. Administrative Science Quarterly 29, 52-73.

Duncan, R. (1972). "Characteristics of organizational environment and perceived environmental uncertainty," Administrative Science Quarterly, 17, 313-327.

Fiedler, F. (1964). A contingency model of leadership effectiveness in L.Berkowitz (ed.). Advances in Experimental Social Psychology, 149-90.

Geletkanycz, M. A., \& Hambrick, D. C. (1997). The external ties of top executives: Implications for strategic choice and performance. Administrative Science Quarterly, 42(4), 654681.

Glantz, J. (2002). Finding your leadership style. A guide for educators. Association for Supervision and Curriculum Development.

Hambrick, D. C., \& Mason, P. A. (1984). Upper echelons: The organization as a reflection of its top managers. Academy of Management Review 9, 193- 206.

Hansen, E. (2006) "Structural panel industry evolution: Implications for innovation and new product development". Forest Policy and Economics, 8(7), 774-783.

Hitt, M. A., \& Irelend, R. D. (1985), "Corporate Distinctive Competence, Strategy, Industry and Performance", Strategic Management Journal, 6(3), 273-293.

Hoang, H., \& Antoncic, B. (2003). Network-based research in entrepreneurship: A critical review. Journal of Business Venturing, 18(2), 165-187.

Hogg, B. A. (1993). European managerial competences. European Business Review, 93(2), 2126.

Homburg, C., Krohmer, H., \& Workman, J. P. (1999). Strategic consensus and performance: The role of strategy type and market-related dynamism. Strategic Management Journal 20, 339-357.

House, R. J. (1977) A 1976 theory of charismatic leadership. In J. G. Hunt and L. L. Larson (Eds.) Leadership: The cutting edge. Carbondale; Southern Illinois University Press.

Javalgi, R. G., Griffith, D. A., \& White, D. S. (2003). An empirical examination of factors influencing the internationalization of service firms. Journal of Services Marketing 17 (2): 185-201. 
Javalgi, R. R. G., Griffith, D. A., \& White, D. S. (2003). An empirical examination of factors influencing the internationalization of service firms. Journal of Services Marketing, 17(2), 185-201.

Johannisson, B. (2000). Networking and entrepreneurial growth. In Sexton, Donald L. Landstrom, Hans (Ed.), The Blackwell handbook of entrepreneurship, 368-386. Oxford; Malden, MA: Blackwell Business.

Jurie, J. D. (2000). Building capacity: Organizational competence and critical theory. Journal of Organizational Change, 13, 264-274.

Kamasak, R. (2017), "The contribution of tangible and intangible resources, and capabilities to a firm's profitability and market performance", European Journal of Management and Business Economics, 26 (2): 252-275

Knight, G. A. (1997), "Firm orientation and strategy under regional market integration", International Executive, 39(3), 351-74.

Koontz, H., \& Donnell, C. (1993). Introduction to Management. McGraw-Hill Inc., New York.

Kopelman, R. E. (2019). Improving organizational performance: The Cube One Framework. Routledge.

Lado, A. A., Boyd, N. G., \& Wright, P. (1992). A competency-based model of sustainable competitive advantage: Toward a conceptual integration. Journal of Management, 18(1), 77-91.

Li, J. J., Poppo, L., \& Zhou, K. Z. (2008). Do managerial ties in China always produce value? Competition, uncertainty, and domestic vs. foreign firms. Strategic Management Journal, 29, 383-400.

Li, L. X. (2000), "An analysis of sources of competitiveness and performance of Chinese manufacturers", International Journal of Operations and Production Management, 20(3), 299-315.

Mahmoud, A. M. (2020). Role of transformational leadership on innovative pro-poor development initiatives in Zanzibar: A case of selected community-based income generating projects in the urban west region, Zanzibar. Universal Journal of Management 8(6), 285-295.

McEvily, B., \& Zaheer, A. (1999). Bridging ties: A source of firm heterogeneity in competitive capabilities. Strategic Management Journal, 20(12), 1133-1156.

McGahan, A., \& Porter, M. (1997). How much does industry matter, really? Strategic Management Journal, 18(Summer Special Issue), 15-30.

McShane, S. L., \& Von Glinow, M. A. (2000). Organizational behavior. Burr Ridge, IL: Irwin/McGraw-Hill.

Mehta, R., Dubinsky, A. J., \& Anderson, R. E. (2003), "Leadership style, motivation and performance in international marketing channels: An empirical investigation of the USA, Finland and Poland", European Journal of Marketing, 37(1/2), 50-85

Messick, D. M., \& Kramer, R. M. (2004). The psychology of leadership: New perspectives and research. Lawrence Erlbaum Associates, Publishers. New Jersey.

Mintzberg, H. (1973), The nature of managerial work. New York: Harper \& Row.

Nguyen, O. T., Liu, L. Y., Haslam, J., \& McLaren, J. (2021). The moderating effect of perceived environmental uncertainty and task uncertainty on the relationship between performance management system practices and organizational performance: evidence from Vietnam. Production Planning \& Control, 1-19.

Obiwuru, T. C., Okwu, A. T., Akpa, V. O., \& Nwankwere, I. A. (2011). Effects of leadership style on organizational performance: A survey of selected small scale enterprises in Ikosi- 
Ketu council development area of Lagos State, Nigeria. Australian Journal of Business and Management Research, 1 (7), 100-111

Paul, A. K., \& Anantharaman, R. N. (2003). Impact of management practices on organizational performance: Analysis of a causal model. International Journal of Human Resource Management, 14(7), 1246-1266.

Pearce, C. L., \& Conger, J. A. (Eds.), (2003), Shared leadership: Reframing the hows and whys leadership. Sage Publications, Thousand Oaks, CA.

Pearce, C. L. (2004). The future of leadership: Combining vertical and shared leadership to transform knowledge work. Academy of Management Executive 18 (1), 47- 57.

Peng, M. W. (2003). Institutional transitions and strategic choices. Academy of Management Review, 28(2), 275-296.

Peng, M. W., \& Heath, P. (1996). The growth of the firm in planned economies in transition: Institutions, organizations, and strategic choice. Academy of Management Review, 21(2), 492-528.

Peng, M. W., \& Luo, Y. (2000). Managerial ties and firm performance in a transition economy: The nature of a micro-macro link. Academy of Management Journal, 43(3), 486-501.

Pinto, J. (2019). Key to effective organizational performance management lies at the intersection of paradox theory and stakeholder theory. International Journal of Management Reviews, 21(2), 185-208.

Pratono, A. H. (2018). Network structure and open innovation: The role of trust in product development. International Journal of Business Innovation and Research, 15(1), 44-61.

Priem, R. L. (1990). Top management group factors, consensus, and firm performance. Strategic Management Journal 11, 469- 478.

Puffer, S. M., \& McCarthy, D. J. (2007). Can Russia's state-managed, network capitalism be competitive? institutional pull versus institutional push. Journal of World Business, 42, 1-13.

Puffer, S. M., McCarthy, D. J., Jaeger, A. M., \& Dunlap, D. (2013). The use of favors by emerging market managers: Facilitator or inhibitor of international expansion?. Asia Pacific Journal of Management

Reed, R., \& DeFillippi, R. (1990). Causal ambiguity, barriers to imitation, and sustainable competitive advantage. Academy of Management Review, 15, 88-102.

Rodriguez, J., \& Walters, K. (2017). The importance of training and development in employee performance and evaluation. World Wide Journal of Multidisciplinary Research and Development, 3(10), 206-212.

Rowe, W. G. (2001). Creating wealth in organizations: The role of strategic leadership. Academy of Management Executive, 15, 81-94.

Sandberg, K., Vinberg, S., \& Pan, Y. (2002). An exploratory study of women in microenterprise: Owner perceptions of economic policy in a rural municipality: Gender-related differences. CD-proceedings of 12th Nordic Conference on Small Business Research, 114.

Simon, H. A. (1955). A behavioral model of rational choice. Quarterly Journal of Economics 69(1), 99- 119.

Stannack, P. (1996). Perspective on employees performance. Management Research News, I19(4/5), 38-40.

Swab, R. G., \& Johnson, P. D. (2019). Steel sharpens steel: A review of multilevel competition and competitiveness in organizations. Journal of Organizational Behavior, 40(2), 147165. 
Switzer, L. N., \& Bourdon, J. F. (2011). Management quality and operating performance: Evidence for Canadian IPOs. International Journal of Business, 16(2), 133.

Tian, X., \& Zhai, X. (2019), "Employee involvement in decision-making: The more the better?", International Journal of Manpower, 40(4), 768-782.

Turner, S., \& Endres, A. (2017). Strategies for enhancing small business owners' success rates. International Journal of Applied Management and Technology, 16(1), 3.

Tushman, M. (1979). Work characteristics and sub-unit communication structure: a contingency analysis. Administrative Science Quarterly 24, 82- 97.

Waldman, D. A., Ramirez, G. G., House, R. J., \& Puranam, P. (2001). Does leadership matter? CEO leadership attributes and profitability under conditions of perceived environmental uncertainty. Academy of Management Journal 44 (1), 134- 143.

Wang, D., Guo, H., \& Liu, L. (2017). One goal, two paths: How managerial ties impact business model innovation in a transition economy. Journal of Organizational Change Management, 30(5), 779-796

Wasserman, S., \& Faust, K. (1994). Social network analysis: Methods and applications Cambridge [England]; New York : Cambridge University Press.

Wright, P.M., \& McMahan, G.C. (1992). Theoretical perspectives for strategic human resource management. Journal of Management, 18, 295-320.

Xu, Q., Chen, J., Xie, Z., Liu, J., Zheng, G., \& Wang, Y. (2007) “Total innovation management: A novel paradigm of innovation management in the 21st century". The Journal of Technology Transfer, 32(1), 9-25.

Zaheer, A., \& Bell, G. G. (2005). Benefiting from network position: firm capabilities, structural holes, and performance. Strategic Management Journal, 26(9), 809-825.

Zhou, K. Z., Poppo, L., \& Yang, Z. (2008). Relational ties or customized contracts? An examination of alternative governance choices in China. Journal of International Business Studies, 39, 526-534.

Zhu, W., Chew, I. K. h., \& Spangler, W. D. (2005). CEO transformational leadership \& organizational outcomes: The mediating role of human-capital-enhancing human resource management. The Leadership Quarterly, 16(1), 39-52. 